\title{
Seasonal dynamics of macroinfaunal key species inhabiting shallow soft-bottoms in the Bay of Blanes (NW Mediterranean)
}

\author{
Rafael Sardá *, Susana Pinedo, Daniel Martin \\ Centro de Estudios Avanzados de Blanes, (C.S.I.C.), Camino de Santa Barbara s/n, 17300-Blanes Girona, \\ Spain. \\ * Corresponding author (fax: +34 972 337806; e-mail: sarda@ceab.csic.es)
}

\begin{abstract}
Within the frame of a wider research project on the littoral ecosystem of the Bay of Blanes (NW Mediterranean), the dynamics of shallow soft-bottom macroinfaunal assemblages of medium-to-fine-sand sediment communities of Spisula subtruncata have been followed since March 1992. These assemblages exhibited a very predictive annual cycle. Abundance and biomass rose sharply during spring, followed by a striking drop through summer showing lower values during autumn and winter. These cycles were consistent with the temporal variation of key macroinfaunal species in these shallow habitats: Spisula subtruncata, Owenia fusiformis, Ditrupa arietina, Lucinella divaricata, Echinocardium mediterraneum, Spio decoratus, Chone infundibuliformis, Paradoneis armata, Mediomastus fragilis, Protodorvillea kefersteini, Branchiostoma lanceolatum, Glycera cf. capitata and Callista chione. These species were included in ecological groups based on the trends observed during the 4 years of seasonal dynamics which are presented.
\end{abstract}

Keywords: Seasonal dynamics / soft-bottom zoobenthos / NW Mediterranean 


\section{INTRODUCTION}

Medium-to-fine-sand Spisula subtruncata communities characterize shallow sublittoral soft-bottoms in the north-western Mediterranean sea [5, 20]. The different facies of this community support high energy flows and show less spatial organization than other sublittoral communities. Besides the large quantity of specific surveys that have been conducted in these shallow waters, detailed descriptions of seasonal patterns in those benthic invertebrate communities are scant $[1,4,7,18]$, and refer mostly to specific components of the community $[3,6]$. In addition, when time-series exist, their duration is relatively short, and in many cases not appropriate for detecting community changes [11].

Monitoring of sublittoral macroinfaunal communities in the Bay of Blanes has been conducted since March 1992. The goals of this study were: (i) to characterize the seasonal dynamics of this community and to relate its temporal variation with other abiotic and biotic compartments of the bay ecosystem; (ii) to conduct detailed growth studies, and to analyse lifecycle patterns and secondary production of the most important species; and (iii) to conduct trend analysis on long-term data so as to predict its changes in relation to natural and/or anthropogenic disturbances. Finally, as this quantitative survey has been established as part of a wider research project, we already had a large amount of information on other biotic systems of the bay such as phytoplankton communities, microheterotrophic planktonic communities, zooplankton and meroplankton communities, fish larvae, phytobenthos, and meiobenthos, and we can examine the relationships between them to assess the forces that drive the seasonal pattern of macroinfaunal communities in this coastal zone.

The purpose of the present study is to present the trends of the most important species of two different soft-bottom benthic assemblages of the medium-to-fine-sand S. subtruncata community in the Bay of Blanes during a 4-year period (1992-1996). We describe the patterns of seasonal changes for the key species of these two assemblages with a temporal resolution ranging between 2 weeks to 2 months. The typology of shapes of the time-series obtained for the key species inhabiting the Bay of Blanes aims to gather together species having similar temporal patterns corresponding to different types of ecological behaviour, thus, we evaluate the shape parameters of these time-series to classify them into the ecological life-cycles types according to Ibanez and Fromentin [15].

\section{MATERIALS AND METHODS}




\subsection{Study area and sampling}

The Bay of Blanes (NW Mediterranean sea, Spain) is an exposed bay which is located between the delta of the river Tordera and the first cliff of the Costa Brava (figure 1). The bay receives different discharges and water flow regimes from the river Tordera combined with intermittent heavy discharges, after storm periods, which also goes into the sea by small closed town creeks. Sublittoral sediments of the bay are also influenced by the Blanes harbour (fisheries and recreational marina), the sewage outfall of the town, which discharges at a distance of $1.5 \mathrm{~km}$ from the coast at a depth of $29 \mathrm{~m}$, and the combined action of the dominant east (Llevant) and south (Garbí) winds. Sublittoral sediments, up to $30 \mathrm{~m}$ depth, consist largely of coarse-to fine-sand sediments, ranging from 129 to 720 microns average grain size. Samples were taken in the Spisula community at two stations located at a depth of $15 \mathrm{~m}$ (figure 1). Station 1 was located in front of the Tordera river (the station had medium to coarse sediments containing $0.24 \%$ silt; its average grain size ranged from 437 to 575 microns, and the organic matter content of these sediments was $0.71 \%$ (range 0.3 to $1.1 \%$ ). Station 2 was located in front of the town of Blanes. This station had fine sediments containing $2.19 \%$ silt; its average grain size ranged from 148 to 169 microns, and the organic matter content of these sediments was $1.08 \%$ (range 0.7 to $1.4 \%$ ).

These two stations have been sampled in the bay since March 1992. The data presented in this paper are from March 1992 to March 1996. During the summer and autumn of 1994, sublittoral shallow soft-bottoms from 10 to $20 \mathrm{~m}$ depth in front of S'Abanell beach were dredged for beach replenishment of several beaches south of the Blanes region. Station 1 was located just in this dredging zone. Sampling was stopped from March 1994 to December 1995 at this station. The later recolonization process has also been analysed (Sardá R., Pinedo S., Gremare A., Taboada S., submitted).

The sampling periodicity (fortnightly to bimonthly) varied according to years and seasons. Biweekly sampling was conducted during the first year-and-a-half for a better knowledge of the dynamic forces that drive the community. Then, the sampling frequency was concentrated during the high recruitment events, and it was decreased during the rest of the year (autumn-winter). At each station, two Van Veen grab samples $\left(600 \mathrm{~cm}^{2}\right)$ were obtained on every sampling date. The grab was able to penetrate to different depths $(15 \mathrm{~cm}$ at station 1 and $12 \mathrm{~cm}$ at station 2) depending on sediment compaction. No biogenic structures were seen on the bottom of the grab samples, indicating the absence of large burrowing organisms. Grab samples were sieved through a $0.5-\mathrm{mm}$ screen on the boat, and preserved in buffered formalin. In addition, two small subsamples were taken from each grab using PVC 
cores covering a surface of approximately $10 \mathrm{~cm}^{2}$. One subsample was used on a weeklybased sampling interval for meiofaunal analysis. The results of this meiofaunal sampling have been reported in Gracía et al. [13]. The other subsample was used to obtain data on the organic content of sediments and for the granulometric analysis.

\subsection{Data analysis}

The organisms retained by the sieve were counted and classified to the lowest possible taxonomic level for polychaetes, bivalves and echinoderms, as well as easily recognized species such as the lancet (Branchiostoma lanceolatum). The rest of the taxa were classified only to major groups. Species biomass was determined as dry weight $\left(24 \mathrm{~h}\right.$ at $\left.60{ }^{\circ} \mathrm{C}\right)$ except for calcified species, where it was obtained by the loss of weight after ashing $\left(5 \mathrm{~h}\right.$ at $\left.450{ }^{\circ} \mathrm{C}\right)$. During our quantitative survey, the life cycle and productivity of the most important macroinfaunal species of the bay have been followed. Depending on the species or taxa, length or width was measured in all individuals through a binocular microscope equipped with a camera lucida and digitizing tablet (Houston Instrument HIPad) linked to a computer. Selected individuals from representative size categories in these species were measured, and then dried for $48 \mathrm{~h}$ at $60{ }^{\circ} \mathrm{C}$ and weighed. Using these data, regressions of length or width vs. dry weight were computed for these species. These regressions were then used to convert future length or width measurements to biomass (table I). Organisms were classified into five trophic groups: (F): filter feeders; (M): mixed (filter and surface-deposit feeders); (S): surfacedeposit feeders; (SS): subsurface-deposit feeders; (C): carnivores/omnivores, using information in Fauchald and Jumars [12] and Dauvin and Ibanez [9]. The bivalve species of the subfamily Tellinoidea and subfamily Nuculoidea were included in the mixed group [16]. The rest of the bivalves were classified as filter feeders.

Organic content of dry sediment was estimated as the loss of weight after ashing. Granulometrical analyses were made using a LS Particle Size Analysis Counter at the Department of Geology of the University of Barcelona. During the course of these timeseries, other environmental data have been obtained using different sources [10].

In order to synthesize the data according to temporal patterns, we employed the framework provided by Ibanez and Fromentin [15] who described a typology of shapes of series (TSS). This method, which consists in the definition of four shape parameters and a classification among the series, revealed six different groups which gather together species 
having similar temporal patterns corresponding to different types of ecological behaviour. We found four of the above mentioned groups when we applied the TSS method to our series.

\section{RESULTS}

\subsection{Assemblage classification and species composition}

The distribution of macroinfaunal species in the shallow soft-bottoms of the Bay of Blanes is related to gradients of sediment granulometry. These gradients arise as a consequence of the delta structure of the bay. Although species composition was similar at the two studied stations, both can be separated as different facies of the medium-to-fine-sand community of Spisula subtruncata. These two facies included: (i) a low-organic medium to coarse-sand facies; and (ii) a low-organic fine-sand facies.

The number of species found in these two stations included 94 species of polychaetes as the major group of fauna, nineteen species of bivalves, and six species of echinoderms. nemerteans and crustaceans, specially amphipods, tanaids, and cumaceans, were also important but were also analysed as a group.

At station 1, low-organic medium to coarse-sand facies, total macroinfaunal abundance averaged 3592 ind $\cdot \mathrm{m}-2$ over the 4-year period, ranging from 21106 in May 1992 to 398 in March 1993. Mean annual biomass averaged $2.26 \mathrm{~g}$ dry weight $\cdot \mathrm{m}-2$, ranging from 5.03 in June 1992 to 0.70 in March 1992. The most important species collected at station 1 are listed in table II. S. subtruncata dominated the facies in density while the most important contributor to the biomass was Callista chione.

At station 2, low-organic fine-sand facies, total macroinfaunal abundance was higher than in the previous considered station. Density averaged $10623 \mathrm{ind} \cdot \mathrm{m}^{-2}$ over the 4 -year period, ranging from 46292 in May 1992 to 1368 in January 1993. Mean annual biomass averaged $2.41 \mathrm{~g}$ dry weight $\cdot \mathrm{m}^{-2}$, ranging from 10.62 in June 1994 to 0.42 in February 1995. Yearly average abundance and biomass for the most important species collected at station 2 are shown in table III. At this station, Owenia fusifomis was the clear dominant species, both in abundance and biomass.

\subsection{Seasonal dynamics of key species}


There was a general seasonal pattern in total macroinfaunal abundance in both facies during the studied period. This general trend is characterized by a peak during spring, a sharp decrease throughout the summer period, and low density values in autumn and winter. The seasonal pattern of biomass follows the pattern of abundance. The observed trends were related to the seasonal dynamics of the most important species in the community: the polychaetes, Owenia fusiformis, Ditrupa arietina, Glycera cf. capitata, Protodorvillea kefersteini, Paradoneis armata, Mediomastus fragilis, Spio decoratus, and Chone infundibuliformis, the bivalves, Spisula subtruncata, Lucinella divaricata, and Callista chione, the echinoderm, Echinocardium mediterraneum, and the cephalocordate, Branchiostoma lanceolata. These thirteen species totalled $65 \%$ of the entire abundance and biomass at station 1, and $69 \%$ in abundance, and $71 \%$ in biomass at station 2 .

Although we did not identify to species level nemerteans (mainly paleonemerteans such as Hubrechtella sp., P. Sundberg pers. comm.), amphipods, cumaceans, and tanaids, they contributed from 8 to $15 \%$ of the total abundance, and from 2 to $8 \%$ of the total biomass of stations 1 and 2, respectively.

Spisula subtruncata, Spio decoratus, Chone infundibuliformis, and Echinocardium mediterraneum were found in similar numbers at the two stations (figure 2) and do not seem to be dependent on the grain size composition of the studied facies. The most abundant was $S$. subtruncata characterized by wide interannual fluctuations, high numbers of recruits (between 5000 to 15000 ind $\cdot \mathrm{m}^{-2}$ ), peaking in April and May, followed by high mortalities in early summer. The population of Spisula is therefore dominated by juveniles with very few survivors 3 months after recruitment. Similar patterns were observed for $S$. decoratus and $C$. infunfibuliformis. However, even if they also have recruitment peaks in spring, the populations of both species are able to maintain a higher number of individuals throughout the year, in contrast to the Spisula population which almost disappears during autumn. These three species seem to have clear annual cycles and no population trends were observed throughout the 4-year period of the study. E. mediterraneum was abundant in 1992, a period of high recruitment. However, heavy mortality followed the recruitment phase and the population has been maintained in low numbers over subsequent years.

Several species were clearly associated with fine-sand particles (figure 3) and Owenia fusiformis was the most abundant of these. Its life cycle was also characterized by a spring peak of recruitment, reaching its maximum density values in June, high mortalities in early summer, and an almost complete disappearance during autumn and winter. Interannual differences in density were very high: peak densities in 1995 were as much as four times lower than those recorded in 1994. The abundance of the bivalve species Lucinella divaricata 
increased between 1992 and 1995 with peaks of recruitment later in the year (June-July). Although its abundance was much lower than the abundance of $S$. subtruncata during the recruitment period, there were ten to fifteen times more individuals of $L$. divaricata than those of S. subtruncata in the sediments during autumn and winter. Two other polychaetes, Paradoneis armata and Mediomastus fragilis were included in the group of species that preferred fine-sand sediments in the bay, showing similar behaviour. Their populations were larger during spring, but they were maintained in high numbers throughout the year.

A third group of species occurred preferentially at station 1 (figure 4). Some of them, Glycera cf. capitata, Protodorvillea kefersteini and Branchiostoma lanceolatum could be considered as accidental species at station 2. The most abundant species in this group was Ditrupa arietina. D. arietina has a life cycle similar to that of S. subtruncata, with high recruitment peaks in May-June followed by dramatic declines to almost zero densities over the winter. Although $D$. arietina was more abundant at the station with larger grain size, an study of the distribution of Ditrupa throughout the Bay of Blanes showed that its preferential habitat is fine-sand sediments between 20 and $30 \mathrm{~m}$ [14]. The densities of G. cf. capitata decreased during the 2 years that we sampled at station 1. From the group of selected species, it was the only organism that did not show a clear recruitment peak throughout the year, and its temporal variation seemed very heterogeneous. P. kefersteini seemed to behave as other polychaete species of the bay, with recruitment phases in spring and a stable population during the rest of the year.

The Cephalocordate, Branchiostoma lanceolatum, showed a contrasting seasonal pattern compared to other macroinfaunal species of the bay. B. lanceolatum reached recruitment peak abundance in early autumn (October), and densities diminished steadily through the autumn and winter. B. lanceolatum is almost absent during spring and summer with few adults living preferentially in the delta frontal coarse sediments of the bay.

The brown-venus clam (Callista chione) was sparsely distributed over much of the bay, and it was not adequately sampled by our grab. C. chione is a commercially valuable species which is actively fished by small crafts in the bay. The growth of this species is slow, taking 4 years to reach $4 \mathrm{~cm}$ in the Mediterranean, attaining its maximum length of $8-8.5 \mathrm{~cm}$ when it is 11-14 years old [23]. We found 45 individuals of C. chione in our two first years of sampling at station 1, and five individuals at station 2 . The analysis of these data did not show any evidence of important recruitment periods, and gave us an indication of its average size in the bay, $2.3 \mathrm{~cm}$ in length (figure 5).

Crustacean species, mostly amphipods, tanaids, and cumaceans, showed seasonal dynamics based on annual cycles (figure 6). Densities increased steadily from winter to spring 
with a peak in June, followed by decreases through summer and autumn. This trend was clear in amphipods and cumaceans, and not so evident for tanaids. The seasonal patterns for nemertean species in the bay showed two main density peaks; the first, and larger one, in June-July, followed by a sharp decline through the summer, and the second, not always evident, in October-November, also followed by a decline through winter.

\section{DISCUSSION}

The abundance and biomass of structured macroinfaunal assemblages at sublittoral stations of the Bay of Blanes showed clear seasonal trends. Abundance and biomass rose sharply during spring, followed by a striking decline through summer and lower values during autumn and winter. This seasonal pattern has been observed at other western Mediterranean sites $[1,4,17,21]$, and contrasts with the pattern seen in similar habitats in North European waters where infaunal peaks are mainly described in summer and early autumn, and minimal values are recorded for winter and early spring $[8,9]$. Seasonal patterns of reproductive events are the main factors which explain such markedly repeated cycles.

In north-west Mediterranean coastal waters, blooms of chlorophyll $a$ concentrations in the water column are observed at the beginning of the year [19]. Release of invertebrate larvae in the Bay of Blanes is synchronized with this bloom (unpubl. data). This synchrony provides the advantage of ensuring an abundant food supply for the larvae [22]. Our observations in the bay showed that most of the invertebrate species with a pelagic larval phase tend to have a similar annual life cycle with peaks of recruitment in spring after a planktonic stage. Ten of the thirteen species that were considered as key species in our studied zone showed this clear annual cycle. The other three species either have annual cycles with different temporal variation, or do not show any clear temporal pattern at all.

The typology of temporal series shapes of the key species analysed allow us to group species with similar temporal patterns, and to classify them into four types.

(1) Species showing annual cycles where new recruits disappear a few months after settlement constituted the first group. Spisula subtruncata, Owenia fusiformis, and Ditrupa arietina could be included in this group. However, O. fusiformis and D. arietina are organisms with high larval release and dispersion, having life cycles longer than a year. Although we did not find large organisms at our stations, adult populations are established in other parts of the bay; the mouth of the Blanes harbour in the case of O. fusiformis, and sandy sediments between 20 and $30 \mathrm{~m}$ depth in the case of $D$. arietina (unpubl. data). S. subtruncata 
showed wide interannual fluctuations. Although its recruitment was always very high, settling specimens showed high mortality rates as has been observed in other Mediterranean sites [2, $3,6]$.

(2) The ecological shape of the obtained time-series for Lucinella divaricata and Echinocardium mediterraneum showed some general interannual tendencies. The population of L. divaricata of the Bay of Blanes has been increasing through the years, while the population of E. mediterraneum was high at the beginning of the study but has declined throughout the bay.

(3) The third, and more numerous group, contains six species. This group includes species that maintain a stable population throughout the year. Five of them, Spio decoratus, Chone infundibuliformis, Paradoneis armata, Mediomastus fragilis, Protodorvillea kefersteini, showed annual population increases during spring. The temporal variation for the lancet, Branchiostoma lanceolatum, showed an opposite pattern, in this case population peaks were observed in autumn and then the population steadily decreased through winter.

(4) The other two species, Glycera cf. capitata and Callista chione, did not show any evident cycle and their temporal variation seemed very heterogeneous. $C$. chione is a bivalve mollusc of economic interest in the Catalan coast. The exploitation of this species took place in the bay during our study. The length frequency distribution of the collected specimens clearly reflect the minimal legal size of captures in the Catalan region $(2.9 \mathrm{~cm}$ following the Catalan law of fisheries).

In conclusion, the medium-to-fine-sand community of Spisula subtruncata in the Bay of Blanes exhibited a very predictive annual cycle, consistent with the temporal variation of the most important macroinfaunal species. These species were included in ecological groups based on the trends observed during these 4 years. The assemblages of this community seem to be regulated by large spring peaks of recruitment followed by a drastic summer crisis.

\section{Acknowledgments}

This research was supported by two CAICYT projects (MAR910503, and AMB940746), by a predoctoral fellowship from the Ministry of Science and Education to Susana Pinedo, and by a postdoctoral fellowship from the CSIC to Daniel Martin. We thank Gustavo Carreras and Fernando Avila for their help during sampling. 


\section{REFERENCES}

[1] Albertelli G., Bonomi A., Covazzi A., Della Croce N., Fraschetti S., Macrobentos y parámetros ambientales en fondos arenosos del Mar de Liguria, Italia, Publ. Espec. Inst. Esp. Oceanogr. 11 (1993) 305-312.

[2] Ambrogi R., Occhipinti Ambrogi A., The estimation of secondary production of the marine bivalve Spisula subtruncata (da Costa) off the Po River Delta, P.S.Z.N.I. Mar. Ecol. 6 (1985) 239-250.

[3] Ambrogi R., Occhipinti Ambrogi A., Temporal variations of secondary production in the marine bivalve Spisula subtruncata off the Po River Delta (Italy), Estuar. Coast. Shelf Sci. 25 (1987) 369-379.

[4] Amoureux J.M., Étude des peuplements infralittoraux de la Côte du Rousillon: III. Variations spatiales et saisonnières, Vie Milieu XXIV (1974) 321-354.

[5] Cardell M.J., Sardà R., Romero J., Spatial changes in sublit-toral soft-bottom polychaete assemblages due to river inputs and sewage discharges, Acta Oecol. 20 (1999) 343-351.

[6] Cattaneo M., Massé H., Importance du recrutement de Spisula subtruncata (da Costa) sur la structure et les fluctuations d'un peuplement benthique, Oceanol. Acta 27 (1983) 63-67.

[7] Danovaro R., Fraschetti S., Belgrano A., Vincx M., Curini-Galetti M., Albertelli G., Fabiano M., The potential impact of meiofauna on the recruitment of macrobenthos in a subtidal coastal benthic community of the Ligurian Sea (north-western Mediterranean): a field result, in: Eleftheriou A., Ansell A.D., Smith C.J. (Eds.), Biology and Ecology of Shallow Coastal waters, Olsen \& Olsen Publ. Fredensborg, 1995, pp. $115-121$.

[8] Dauvin J.C., Dynamique d'écosystèmes macrobenthiques des fonds sédimentaires de la baie de Morlaix et leur perturbation par les hydrocarbures de l'Amoco Cadiz, université P.-et-M.-Curie, Paris, 1984, 468 p.

[9] Dauvin J.C., Ibanez F., Variations à long-terme (1977-1985) du peuplement des sables fins de la Pierre Noire (Baie de Morlaix, Manche Occidentale): analyse statistique de l'évolution structurale, Hydrobiologia 142 (1986) 171-186.

[10] Duarte C.M., Seasonality in Blanes Bay: a paradigm of the Northwest Mediterranean littoral, Publ. Espec. Inst. Esp. Oceanogr. 22 (1996) 1-78.

[11] Duarte C.M., Cebrian J., Marbà N., Uncertainty of detecting sea changes, Nature 356 (1992) 190.

[12] Fauchald K., Jumars P., The diet of worms: a study of polychaete feeding guilds, Oceanogr. Mar. Biol. Annu. Rev. 17 (1979) 193-284.

[13] Gracia L., Bayò G., Palacín C., Duarte C.M. Temporal fluctuations of sublittoral meiofauna in sandy Blanes Bay (NW Mediterranean), in: Duarte C.M. (Ed.), Seasonality in Blanes Bay: a Paradigm of the Northwest Mediterranean Littoral, Publ. Espec. Inst. Esp. Oceanogr. 22 (1996) 55-61.

[14] Gremare A., Sarda R., Medernach L., Jordana E., Pinedo S., Amouroux J.M., Martin D., Nozais C., Charles F., On the dramatic increase of Ditrupa arietina O. F. Müller (Annelida: Polychaeta) along both the French and the Spanish Catalan Coasts, Estuar. Coast. Shelf Sci. 47 (1998) 447-458.

[15] Ibanez M., Fromentin J.M., Une typologie à partir de la forme des séries chronologiques (TFS), Oceanol. Acta 20 (1997) 11-25.

[16] Levinton J.S., Marine Ecology, Prentice-Hall Inc., Englewood Cliffs NJ, 1982, 526 p. 
[17] Massé H., Contribution a l'étude de la macrofaune de peuplements des sables fin infralittoraux des côtes de Provence. VII Discussion, comparison, et interpretation des données quan-titative, Tethys 4 (1972) 397422.

[18] Massé H., Guérin J.P., Étude expérimentale sur le recrutement des espèces de la macrofaune benthique des substrats meubles. 2-Données sur les cycles biologiques des Polychètes et des Bivalves, Tethys 8 (1978) 283-294.

[19] Mura M.P., Agusti S., Cebrian J., Satta M.P., Duarte C.M. Seasonal variability of planktonic gross primary production in Blanes Bay (March 1992-March 1994), in: Duarte C.M. (Ed.), Seasonality in Blanes Bay: a Paradigm of the Northwest Mediterranean Littoral, Publ. Espec. Inst. Esp. Oceanogr. 22 (1996) 31-38.

[20] Pérês J.M., Picard J., Nouveau manuel de bionomie benthique de la mer Méditerranée, Recl. Trav. Stn. Mar. Endoume. Fac. Sci. Mars 31 (1964) 1-138.

[21] Sardá R., Martin D., Pinedo S., Dueso A., Cardell M.J., Seasonal dynamics of shallow soft-bottom communities in Western Mediterranean, in: Eleftheriou A., Ansell A.D., Smith

C.J. (Eds.), The Biology and Ecology on Shallow Coastal Waters, Olsen \& Olsen, Fredensborg, 1995, pp. 191198.

[22] Starr M., Himmelman J.H., Therriault J.C., Direct coupling of marine invertebrate spawning with phytoplankton blooms, Science 247 (1990) 1071-1074.

[23] Strada R., Zocco M., Dàti Preliminari sull'accrescimento di Callista chione in Adriatico Settentrionale, Oebalia XI (1985) 829-831. 


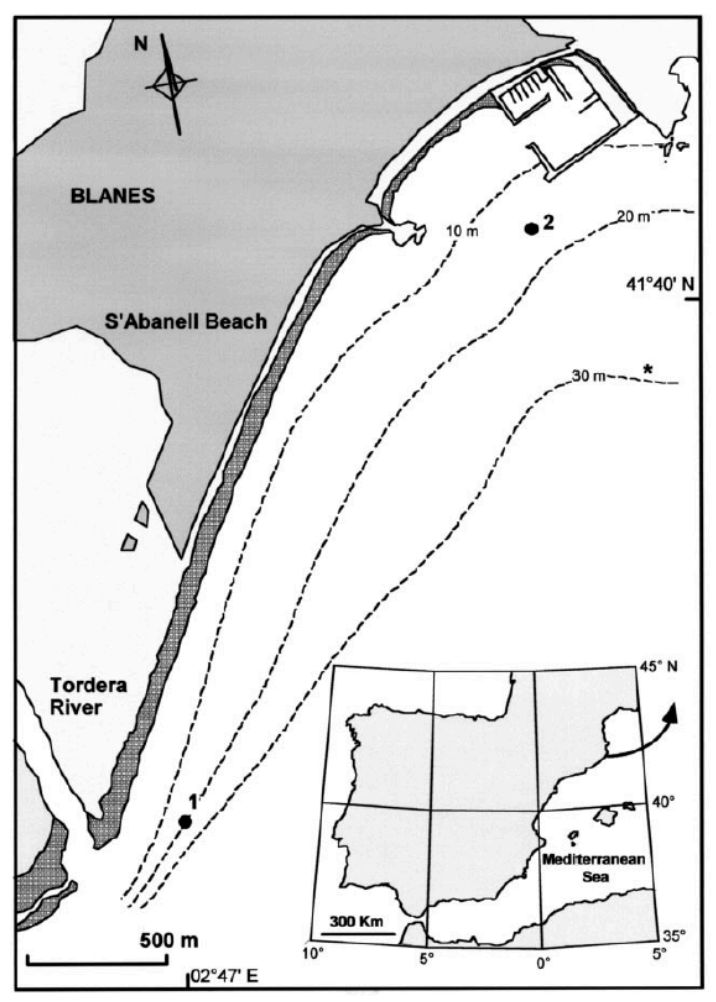

Figure 1. Stations (1 and 2) in the Bay of Blanes. The asterisk indicates the submarine outfall of the town. 

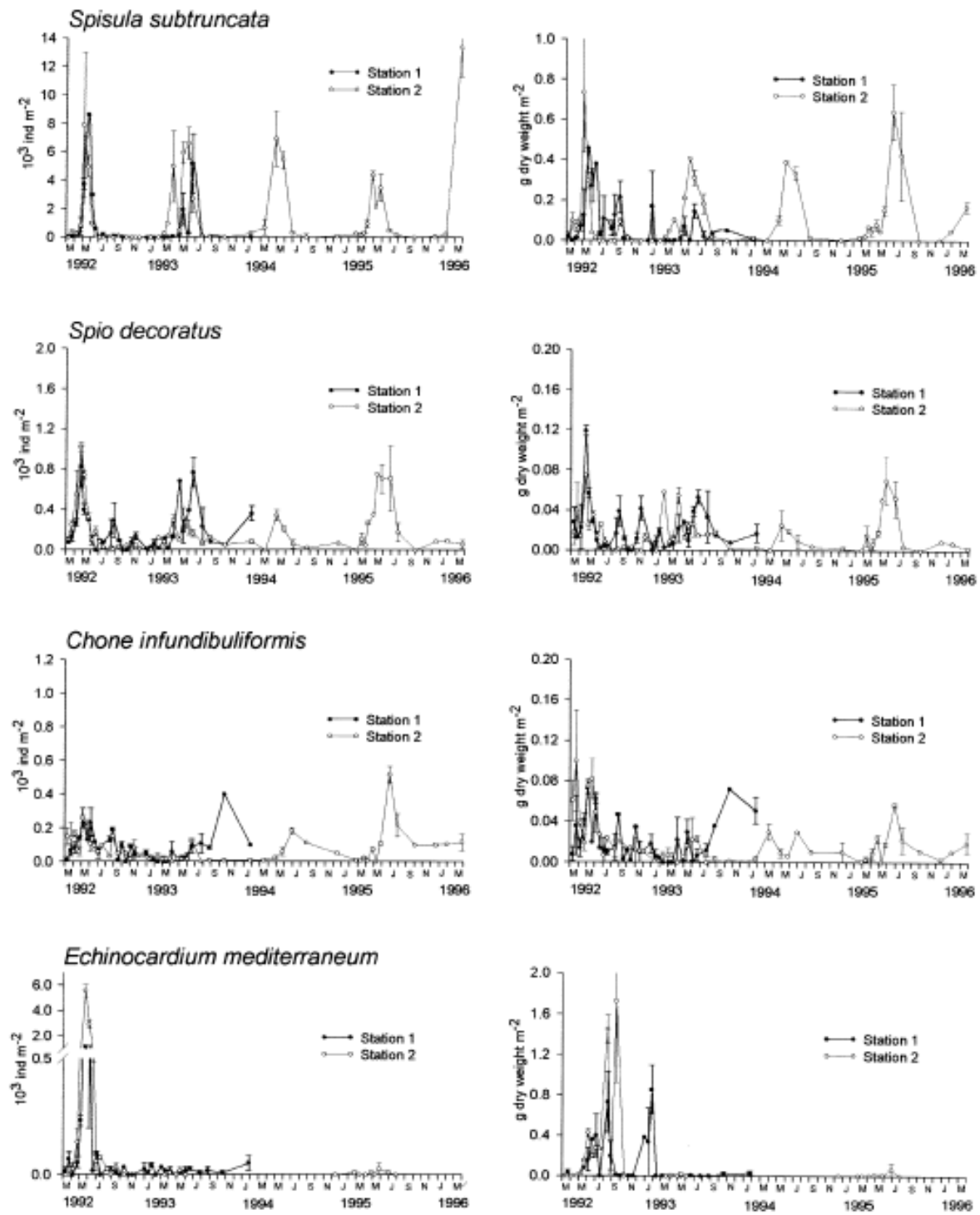

Figure 2. Abundance (left) and biomass (right) of macroinfaunal key species with similar abundances at both stations (1 and 2). 

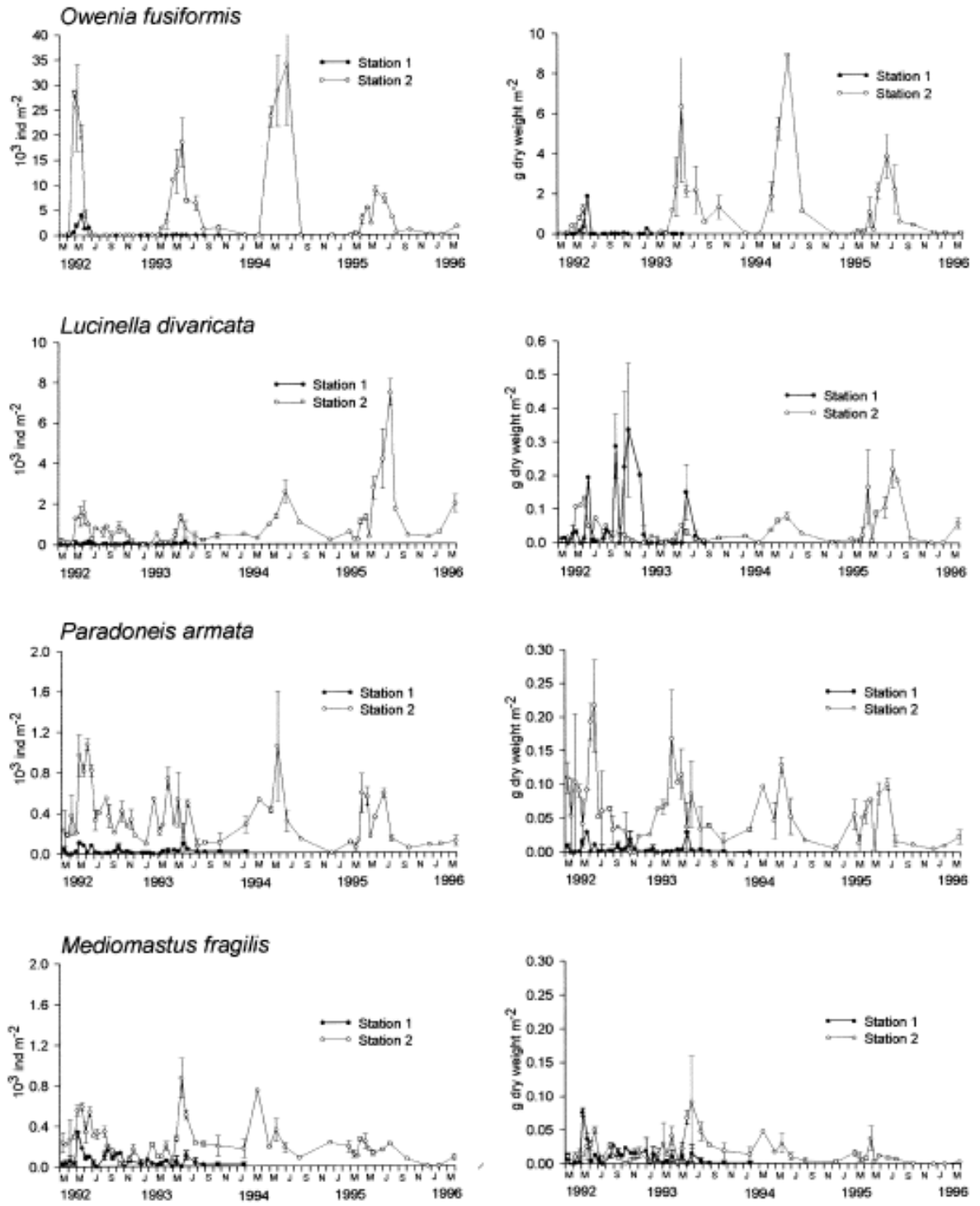

Figure 3. Abundance (left) and biomass (right) of macroinfaunal key species which preferred fine-sand sediments. 

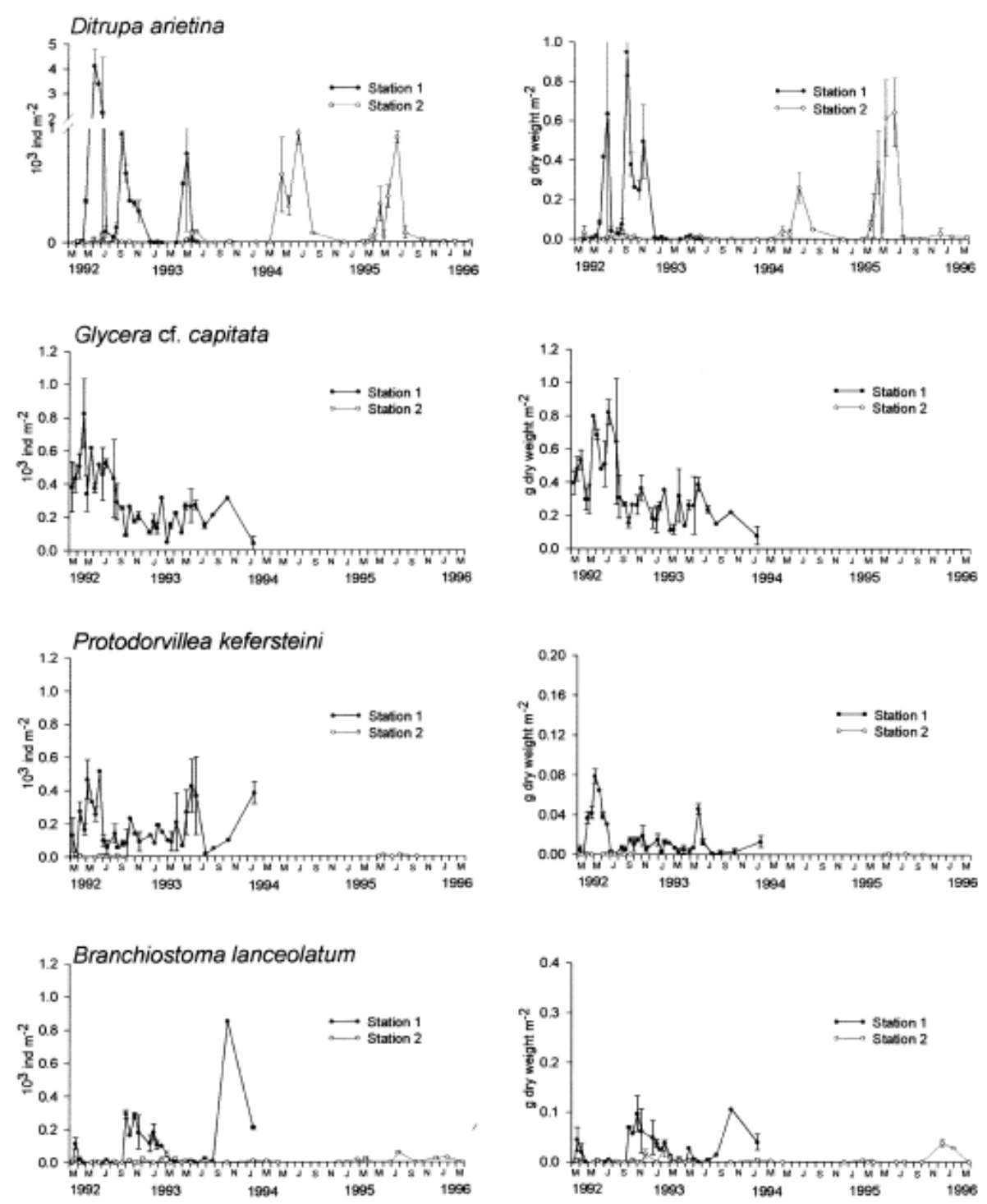

Figure 4. Abundance (left) and biomass (right) of macroinfaunal key species which preferred medium-to coarsesand sediments. 


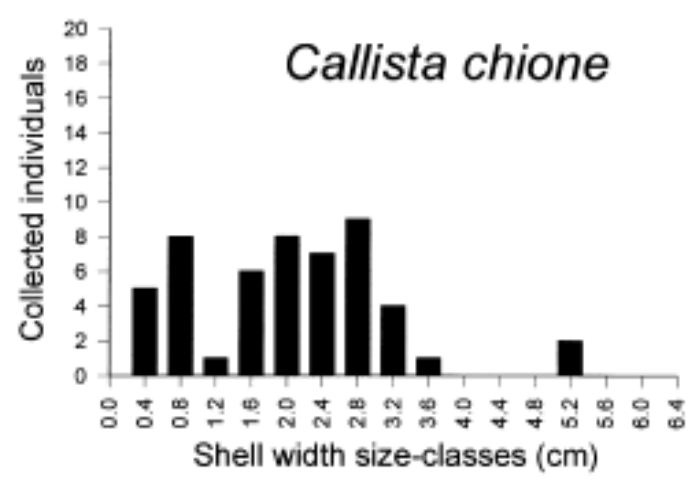

Figure 5. Shell width frequency distribution of the specimens ofCallista chione collected in the bay during the first 2 years of survey. 

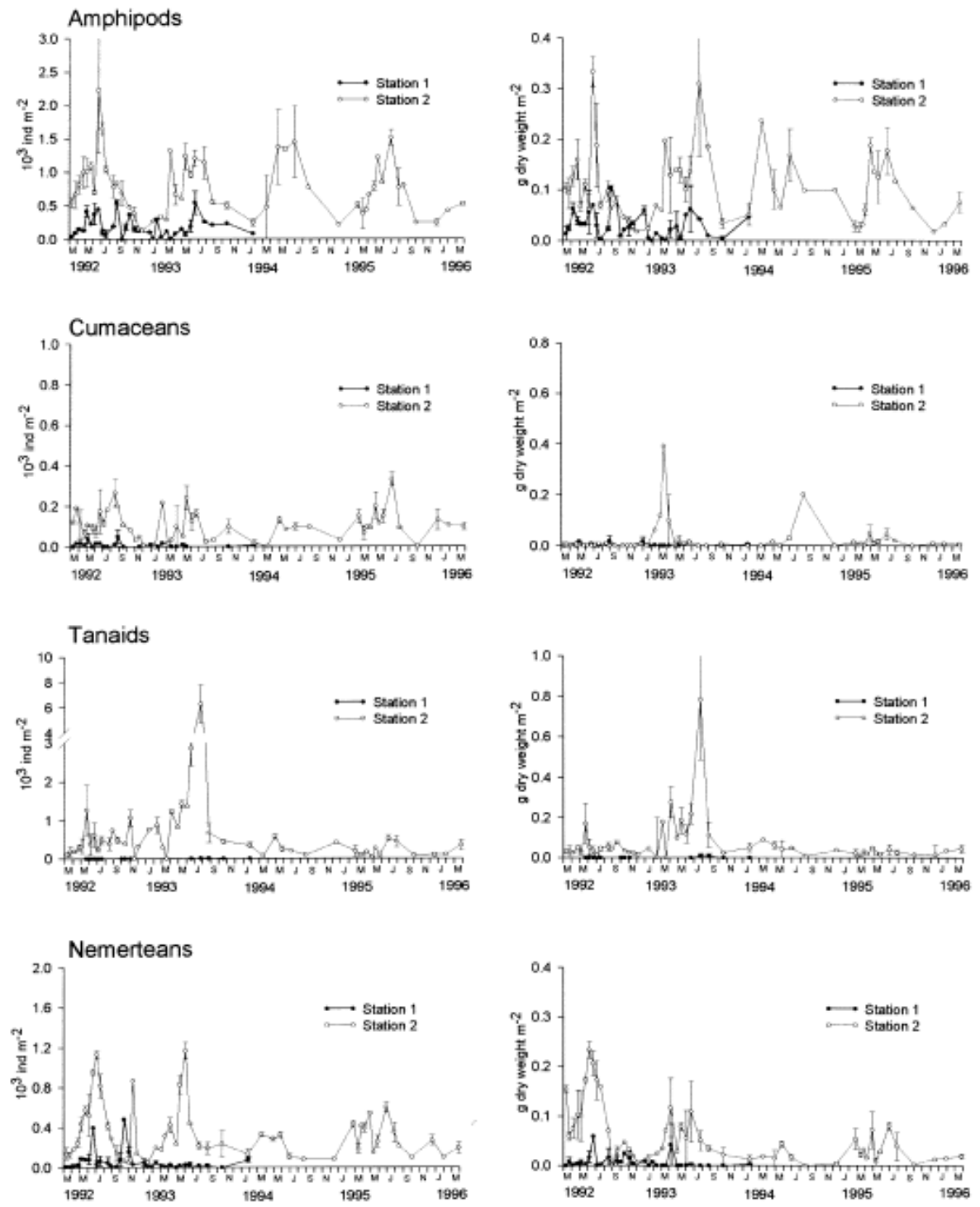

Figure 6. Abundance (left) and biomass (right) of other important group of taxa (see text). 
Table I. Regressions used to convert length or width ( $\mathrm{mm}$ ) to biomass (mg). $n$ is the number of specimens used in the regression.

\begin{tabular}{lccc}
\hline Species & Regression equation & $r^{2}$ & $n$ \\
\hline $\begin{array}{l}\text { Length between the fourth and fifth setiger (a) } \\
\text { Owenia fusiformis (Pol.) }\end{array}$ & $0.3277(\mathrm{a})^{1.844}$ & 0.81 & 107 \\
Maximum tube diameter (b) & & & \\
Owenia fusiformis (Pol.) & $0.8434(\mathrm{~b})^{2.177}$ & 0.85 & 81 \\
Diameter of tube aperture (c) & & & \\
Ditrupa arietina (Pol.) & $0.4522(\mathrm{c})^{3.992}$ & 0.88 & 34 \\
Shell width (d) & & & \\
Callista chione (Biv.) & $0.0210(\mathrm{~d})^{2.687}$ & 0.95 & 24 \\
Corbula gibba (Biv.) & $0.0036(\mathrm{~d})^{3.196}$ & 0.91 & 26 \\
Chamelea gallina (Biv.) & $0.0052(\mathrm{~d})^{3.153}$ & 0.95 & 19 \\
Dosinia lupinus (Biv.) & $0.0210(\mathrm{~d})^{2.477}$ & 0.89 & 33 \\
Loripes lacteus (Biv.) & $0.0140(\mathrm{~d})^{2.737}$ & 0.77 & 53 \\
Lucinella divaricata (Biv.) & $0.0090(\mathrm{~d})^{3.199}$ & 0.85 & 57 \\
Spisula subtruncata (Biv.) & $0.0099(\mathrm{~d})^{2.937}$ & 0.93 & 37 \\
Tellina pulchella (Biv.) & $0.0090(\mathrm{~d})^{2.617}$ & 0.95 & 20 \\
Thracia papiracea (Biv.) & $0.0249(\mathrm{~d})^{2.208}$ & 0.86 & 20 \\
\hline
\end{tabular}


Table II. Species composition, mean annual macroinfaunal abundance (ind $\cdot \mathrm{m}-2$ ), mean annual macroinfaunal biomass (g dry weight $\cdot \mathrm{m}-2$ ), and abundance and biomass average values for the 4-year period of constant species at station 1. Annual means are based on a 12-month period of time, between March of this year and March of the successive year.

\begin{tabular}{|c|c|c|c|c|c|c|c|}
\hline \multicolumn{2}{|c|}{ Rank by frequency } & \multicolumn{3}{|c|}{ Abundance } & \multicolumn{3}{|c|}{ Biomass } \\
\hline & & \multirow{2}{*}{$\begin{array}{r}1992 \\
735\end{array}$} & \multirow{2}{*}{$\begin{array}{r}1993 \\
452\end{array}$} & \multirow{2}{*}{$\begin{array}{c}\text { Average } \\
594\end{array}$} & \multirow{2}{*}{$\begin{array}{l}1992 \\
0.096\end{array}$} & \multirow{2}{*}{$\begin{array}{c}1993 \\
0.026\end{array}$} & \multirow{2}{*}{$\begin{array}{c}\text { Average } \\
0.061\end{array}$} \\
\hline 1 & Spisula subtruncata (Biv), $\mathrm{F}$ & & & & & & \\
\hline 2 & Ditrupa arietina (Pol.), F & 703 & 87 & 395 & 0.192 & 0.002 & 0.097 \\
\hline 3 & Glycera cf. capitata (Pol), C & 351 & 200 & 276 & 0.390 & 0.175 & 0.282 \\
\hline 4 & Owenia fusiformis (Pol.), M & 418 & 12 & 215 & 0.119 & 0.005 & 0.062 \\
\hline 5 & Protodorvillea kefersteini (Pol.), C & 193 & 203 & 198 & 0.019 & 0.008 & 0.014 \\
\hline 6 & Spio decoratus (Pol.), S & 146 & 240 & 193 & 0.020 & 0.021 & 0.020 \\
\hline 7 & Branchiostoma lanceolatum (Cef.), F & 127 & 237 & 182 & 0.027 & 0.028 & 0.028 \\
\hline 8 & Chone infundibuliformis (Pol.) $\mathrm{M}$ & 89 & 144 & 117 & 0.020 & 0.033 & 0.026 \\
\hline 9 & Echinocardium mediterraneum (Equ.), S & 106 & 27 & 67 & 0.153 & 0.013 & 0.083 \\
\hline 10 & Syllis sp. (Pol.), C & 65 & 66 & 66 & 0.016 & 0.004 & 0.010 \\
\hline 11 & Sphaerosyllis taylori (Pol.), C & 104 & 22 & 63 & 0.004 & 0.001 & 0.002 \\
\hline 12 & Mediomastus fragilis (Pol.), SS & 94 & 31 & 63 & 0.014 & 0.003 & 0.009 \\
\hline 13 & Sigambra tentaculata (Pol.), C & 103 & 20 & 62 & 0.012 & 0.001 & 0.007 \\
\hline 14 & Gyptis rosea (Pol.), C & 75 & 14 & 45 & 0.004 & 0.001 & 0.002 \\
\hline 15 & Capitella capitata (Pol.), SS & 33 & 53 & 43 & 0.003 & 0.001 & 0.002 \\
\hline 16 & Lumbrineris acuta (Pol.), C & 78 & 7 & 43 & 0.056 & 0.006 & 0.031 \\
\hline 17 & Parapionosyllis elegans (Pol.), C & 64 & 18 & 41 & 0.002 & 0.001 & 0.001 \\
\hline 18 & Thracia papiracea (Biv), $\mathrm{F}$ & 32 & 31 & 32 & 0.028 & 0.010 & 0.019 \\
\hline 19 & Paradoneis armata (Pol.), S & 30 & 28 & 29 & 0.004 & 0.003 & 0.003 \\
\hline 20 & Cauleriella bioculata (Pol.), S & 32 & 21 & 27 & 0.012 & 0.020 & 0.016 \\
\hline 21 & Polygordius sp. (Pol.), S & 21 & 30 & 26 & 0.002 & 0.000 & 0.001 \\
\hline 22 & Lucinella divaricata (Biv), , F & 41 & 9 & 25 & 0.078 & 0.001 & 0.040 \\
\hline 23 & Micronephthys mariae (Pol.), C & 14 & 35 & 25 & 0.002 & 0.027 & 0.014 \\
\hline 24 & Prionospio malmgremi (Pol.), S & 40 & 7 & 24 & 0.005 & 0.001 & 0.003 \\
\hline 25 & Chaetozone setosa (Pol.), S & 0 & 43 & 22 & 0.000 & 0.008 & 0.004 \\
\hline 33 & Callista chione (Biv.), $\mathrm{F}$ & 16 & 5 & 11 & 1.179 & 0.729 & 0.954 \\
\hline & Ophiura texturata (Equ.), S & 6 & 1 & 4 & 0.114 & 0.000 & 0.057 \\
\hline & Dosinia lupinus (Biv.), $\mathrm{F}$ & 3 & 4 & 4 & 0.047 & 0.007 & 0.027 \\
\hline & al macroinfauna & 4680 & 2504 & 3592 & 3.126 & 1.399 & 2.260 \\
\hline
\end{tabular}


Table III. Species composition, mean annual macroinfaunal abundance (ind $\cdot \mathrm{m}-2$ ), mean annual macroinfaunal biomass ( $g$ dry weight $\cdot \mathrm{m}-2$ ), and abundance and biomass average values for the 4-year period of constant species at station 2. Annual means are based on a 12-month period of time, between March of this year and March of the successive year.

\begin{tabular}{|c|c|c|c|c|c|c|c|c|c|c|c|}
\hline \multicolumn{2}{|c|}{ Rank by frequency } & \multicolumn{5}{|c|}{ Abundance } & \multicolumn{5}{|c|}{ Biomass } \\
\hline & & \multirow{2}{*}{$\begin{array}{l}1992 \\
3257\end{array}$} & \multirow{2}{*}{$\begin{array}{r}1993 \\
3746\end{array}$} & \multirow{2}{*}{$\begin{array}{l}1994 \\
9371\end{array}$} & \multirow{2}{*}{$\begin{array}{l}1995 \\
2008\end{array}$} & \multirow{2}{*}{$\begin{array}{r}\text { Average } \\
4596\end{array}$} & \multirow{2}{*}{$\begin{array}{c}1992 \\
0.123\end{array}$} & \multirow{2}{*}{$\begin{array}{l}1993 \\
1.154\end{array}$} & \multirow{2}{*}{$\begin{array}{r}1994 \\
1.996\end{array}$} & \multirow{2}{*}{$\begin{array}{l}1995 \\
0.861\end{array}$} & \multirow{2}{*}{$\begin{array}{r}\text { Average } \\
1.033\end{array}$} \\
\hline 1 & Owenia fusiformis (Pol.), M & & & & & & & & & & \\
\hline 2 & Spisula subtruncata (Biv.), F & 652 & 1246 & 1189 & 560 & 912 & 0.065 & 0.076 & 0.090 & 0.126 & 0.089 \\
\hline 3 & Lucinella divaricata (Biv.), $\mathrm{F}$ & 500 & 423 & 925 & 1623 & 868 & 0.032 & 0.015 & 0.029 & 0.070 & 0.036 \\
\hline 4 & Paradoneis armata (Pol.), $\mathrm{S}$ & 494 & 308 & 264 & 206 & 318 & 0.059 & 0.055 & 0.043 & 0.028 & 0.047 \\
\hline 5 & Mediomastus fragilis (Pol.), SS & 231 & 323 & 235 & 94 & 221 & 0.013 & 0.030 & 0.014 & 0.006 & 0.016 \\
\hline 6 & Spio decoratus (Pol.), S & 149 & 109 & 75 & 224 & 139 & 0.015 & 0.012 & 0.006 & 0.014 & 0.012 \\
\hline 7 & Magelona mimuta (Pol.), S & 407 & 16 & 25 & 27 & 119 & 0.021 & 0.001 & 0.003 & 0.002 & 0.007 \\
\hline 8 & Echinocardium mediterraneum (Equ.), $\mathrm{S}$ & 429 & 2 & 1 & 1 & 108 & 0.259 & 0.000 & 0.000 & 0.006 & 0.066 \\
\hline 9 & Ditrupa arietina (Pol.), F & 8 & 11 & 243 & 157 & 105 & 0.008 & 0.002 & 0.128 & 0.231 & 0.092 \\
\hline 10 & Capitella capitata (Pol.), SS & 256 & 25 & 18 & 75 & 94 & 0.012 & 0.002 & 0.001 & 0.003 & 0.005 \\
\hline 11 & Chone infundibuliformis (Pol.), $\mathrm{M}$ & 82 & 13 & 72 & 163 & 82 & 0.026 & 0.007 & 0.015 & 0.016 & 0.016 \\
\hline 12 & Myriochele oculata (Pol.), M & 57 & 54 & 87 & 113 & 78 & 0.021 & 0.014 & 0.018 & 0.024 & 0.019 \\
\hline 13 & Exogone hebes (Pol.), C & 128 & 53 & 38 & 64 & 71 & 0.005 & 0.002 & 0.002 & 0.002 & 0.003 \\
\hline 14 & Thracia papiracea (Biv), F & 61 & 57 & 128 & 34 & 70 & 0.005 & 0.004 & 0.237 & 0.007 & 0.063 \\
\hline 15 & Prionospio caspersi (Pol.), S & 103 & 4 & 16 & 136 & 65 & 0.009 & 0.001 & 0.001 & 0.013 & 0.006 \\
\hline 16 & Spiophanes bombyx (Pol.), S & 37 & 82 & 103 & 24 & 61 & 0.000 & 0.006 & 0.009 & 0.004 & 0.005 \\
\hline 17 & Spiochaetopterus costarum (Pol.), M & 152 & 39 & 14 & 20 & 56 & 0.090 & 0.040 & 0.014 & 0.013 & 0.039 \\
\hline 18 & Exogone verugera $(\mathrm{Pol}),. \mathrm{C}$ & 25 & 20 & 37 & 128 & 52 & 0.002 & 0.001 & 0.001 & 0.005 & 0.002 \\
\hline 19 & Micronephthys mariae (Pol.), C & 69 & 27 & 45 & 50 & 48 & 0.004 & 0.008 & 0.007 & 0.005 & 0.006 \\
\hline 20 & Ensis ensis (Biv.), $\mathrm{F}$ & 37 & 43 & 72 & 15 & 42 & 0.000 & 0.000 & 0.001 & 0.000 & 0.000 \\
\hline 21 & Sigambra tentaculata (Pol), C & 81 & 9 & 30 & 22 & 36 & 0.007 & 0.002 & 0.003 & 0.002 & 0.004 \\
\hline 22 & Aricidea (Acmira.) sp. (Pol.), S & 41 & 15 & 47 & 29 & 33 & 0.005 & 0.003 & 0.004 & 0.004 & 0.004 \\
\hline 23 & Glycera rouxii (Pol.), C & 8 & 22 & 63 & 34 & 32 & 0.019 & 0.031 & 0.022 & 0.020 & 0.023 \\
\hline 24 & Tellina sp. (Biv.), M & 47 & 8 & 33 & 33 & 30 & 0.004 & 0.000 & 0.001 & 0.007 & 0.003 \\
\hline 25 & Poecilochaetous serpens (Pol.), S & 52 & 15 & 29 & 10 & 26 & 0.002 & 0.003 & 0.004 & 0.001 & 0.003 \\
\hline 68 & Callista chione (Biv.), $\mathrm{F}$ & 1 & 3 & 3 & 1 & 2 & 0.004 & 0.376 & 0.083 & 0.194 & 0165 \\
\hline 28 & Sigalion squamatum (Pol.), C & 10 & 14 & 37 & 19 & 20 & 0.056 & 0.015 & 0.089 & 0.009 & 0.042 \\
\hline 33 & Nephthys cirrosa (Pol.), C & 44 & 5 & 1 & 1 & 12 & 0.017 & 0.008 & 0.045 & 0.037 & 0.027 \\
\hline & al macroinfauna & 10122 & 9324 & 15302 & 7617 & 10623 & 1.690 & 2.541 & 3.097 & 2.300 & 2.407 \\
\hline
\end{tabular}

